\title{
KNOWLEDGE AND CONCERNS FOR ORGAN DONATION AMONGST NURSING STUDENTS AND NURSING STAFF IN AN APEX MEDICAL INSTITUTE IN A METROPOLITAN CITY
}

\author{
Amol Kinge1, Kamaxi Bhate2 ${ }^{2}$ Ashwini Yadav³, Parth Vyas ${ }^{4}$ \\ ${ }^{1}$ Epidemiologist Cum Assistant Professor, Department of Community Medicine, SBHGMC, Dhule. \\ ${ }^{2}$ Professor, Department of Community Medicine, Seth GSMC and KEM Hospital, Parel, Mumbai. \\ ${ }^{3}$ Resident Medical Officer, Department of Community Medicine, Seth GSMC and KEM Hospital, Parel, Mumbai. \\ ${ }_{4}^{4}$ Assistant Professor, Department of Community Medicine, SBHGMC, Dhule.
}

\begin{abstract}
\section{BACKGROUND}

Organ donation is one of the greatest advances of modern science. Since the Transplantation of Human Organs Act (THO Act) was passed in India, in 1994, Organ transplant activity was possible from Brain Stem dead donors in India. We have actual organ donation rate for cadaver in India is currently 0.05 per million population. Education programs have recently been suggested as a new approach in solving the organ shortage. This study intends to assess the awareness about organ donation among young Nursing students and staff in a tertiary apex institute in a metropolitan area.

Aims and Objectives - To assess the knowledge and address the concerns about organ donation among nursing staff and identifying the de-motivating factors in organ donation and hence to evolve strategies for promotion of organ donation among them.
\end{abstract}

\section{MATERIALS AND METHODS}

It was a cross-sectional study, 98 nursing students and nursing staff working in Apex Medical in Metropolitan area who consented to participate in the study were enrolled in this study using universal sampling method. A pretested, semi-structured questionnaire was used to collect information by interview.

\section{RESULTS}

Among all the 98 participants, 83\% participants knew the terminology of organ donation; only 50\% participants said that organ can be donated by living donor as well as after death. Only $39 \%$ knew about the fact that brain stem death and coma are different; however, their knowledge was inadequate. Only 52\% knew that close relative's consent is important before organ donation. About half of the participants (46\%) felt that organ donation is accepted by all religions. About $69 \%$ participants were found willing to donate their organs after their brain stem death and about $62 \%$ were willing to donate their relative's organs.

\section{CONCLUSION}

Nursing staff is the most important caretaker of the patients when patients are indoor or in intensive care units. Though majority of participants were aware of terminology of Organ Donation, they did not have appropriate knowledge regarding the concept.

\section{KEYWORDS}

Organ Donation, Brain Stem Death, Living Donor.

HOW TO CITE THIS ARTICLE: Kinge A, Bhate K, Yadav A, et al. Knowledge and concerns for organ donation amongst nursing students and nursing staff in an Apex Medical Institute in a Metropolitan City. J. Evolution Med. Dent. Sci. 2017;6(13):991-993, DOI: $10.14260 / \mathrm{Jemds} / 2017 / 212$

\section{BACKGROUND}

Nowadays, organ donation became a typical procedure to save life and improve the lives of the patients that have a chance to survive.(1) In India, according to Human Organ Transplantation Act (HOTA Act) was passed in India in 1994; it has been possible to undertake multi-organ transplant activity from Brain Stem Dead donors.(2) The rate of organ donation is relatively low in Asia. Therefore, understanding the attitude and knowledge of individuals that affect their willingness to commit as an organ donor is crucial to develop effective educational programs that raise public awareness

Financial or Other, Competing Interest: None.

Submission 04-01-2017, Peer Review 29-01-2017,

Acceptance 03-02-2017, Published 13-02-2017.

Corresponding Author:

Dr. Amol Kinge,

Department of Community Medicine,

Chakkarbardi, SBHGMC, Dhule-424001.

E-mail: dramolkinge@gmail.com

DOI: $10.14260 /$ jemds $/ 2017 / 212$

(c) (i) $(-)$ and commitment toward organ donation.(3) Because of high number of road traffic accidents in India, there is a lot of potential for deceased organ donations if utilised legitimately.(4) Among 100,000 of people dying each year are believed to be potential donors; however, only less than 200 actually become donors.(5) The waiting list of patients requiring organs is increasing day by day. The issue of organ donation is complex and multifactorial involving ethical, legal, medical, organisational and societal factors.(6) Countries around the world have reported that people's attitudes toward organ donation are influenced by factors such as knowledge, education and religion. The knowledge, attitudes and behaviours of the health care professionals are important factors in creating an environment that positively influence organ donation rate.(4) This study intends to assess the awareness about Organ Donation among nursing students and nursing staff in a Tertiary Apex Institute in a Metropolitan area.

\section{MATERIALS AND METHODS}

It was a cross-sectional study, about 98 nursing students and nursing staff working in Apex Medical in Metropolitan area 
who consented to participate in the study were enrolled in this study using Universal sampling method. A pretested, semi-structured questionnaire was used to collect information by interview. The questionnaire was validated by authorities from Zonal Transplant Coordination Committee. Data was collected after Institutional Ethical Committee permission from participants by using the pre-validated questionnaire, and at the end of data collection participants were asked to fill pledge forms and Donor cards in order to see their wish to donate the organs after Brain stem death. Appropriate and correct information was given to all the participants at the end of data collection using presentations, informative reading material in the form of pamphlets. The data was tabulated and analysed for frequencies using MS Excel Software 20.0.

\section{RESULTS}

The present study was done among 98 participants consisting nursing students and staff nurses working in medical college who consented to participate in the study.

All the participants were between age group of 20 to 50 years, whereas majority of participants were among 20 to 30 years of age group (51\%) since majority of participants were nursing students. Majority of participants were Hindu (77\%) by religion, others were Buddhist (22.44\%), Muslim (5.1\%) and Christian (4.08\%).

Among all the participants 83\% students were knowing the terminology of Organ Donation, though very few had accurate knowledge about Organ Donation. Only 50\% participants said that Organ can be donated by Living Donor as well as after death (Figure 1). Only 39\% participants were found aware about the fact that brain stem death and Coma are different; however, among those very few could tell the exact difference between coma and brain stem death. Awareness about importance of close relative's consent was also found lacking among participants, only 52\% participants knew that close relative's consent is important before organ donation (Table 2). Although very few participants could enumerate various close relatives permitted for consent according to legislation. Only 35\% participants were aware about the above important fact. The process of Organ Donation in India is controlled and regulated by Transplantation of Human Organ and Tissues Act 1994 with several amendments. Only $30 \%$ of participants were aware about this fact that organ donation is regulated by Law (Figure 2). About half of the participants (46\%) felt that organ donation is accepted by all religions. Though half of the participants were not sure about religious acceptance of organ donation; 69\% participants were found willing to donate their organs after their Brain stem death, while others responded that they wanted to consult families (Table 4). About $62 \%$ of participants were found willing to donate their relative's organs after their brain stem death (Table 3 ).

\begin{tabular}{|c|c|c|}
\hline $\begin{array}{c}\text { Whether Brain } \\
\text { Stem Death and } \\
\text { COMA are } \\
\text { different }\end{array}$ & $\begin{array}{c}\text { Number of } \\
\text { Students }\end{array}$ & Percentage \\
\hline Yes & 38 & 38.77 \\
\hline No & 42 & 42.85 \\
\hline Do not know & 18 & 18.36 \\
\hline Total & 98 & $100 \%$ \\
\hline \multicolumn{3}{|c|}{$\begin{array}{l}\text { Table 1. Knowledge about Difference between } \\
\text { Brain Stem Death and Coma }\end{array}$} \\
\hline
\end{tabular}

\begin{tabular}{|c|c|c|}
\hline $\begin{array}{c}\text { Consent of } \\
\text { Relatives is } \\
\text { Important }\end{array}$ & $\begin{array}{c}\text { Number of } \\
\text { Students }\end{array}$ & Percentage \\
\hline Yes & 51 & 52.04 \\
\hline No & 25 & 25.51 \\
\hline Do not know & 23 & 23.46 \\
\hline Total & 98 & $100 \%$ \\
\hline Table 2. Knowledge about Importance \\
of Relative's Consent \\
\hline
\end{tabular}

\begin{tabular}{|c|c|c|}
\hline $\begin{array}{c}\text { Are you Willing to } \\
\text { Donate your } \\
\text { Relatives Organs } \\
\text { after BSD }\end{array}$ & $\begin{array}{c}\text { Number of } \\
\text { Students }\end{array}$ & Percentage \\
\hline Yes & 61 & 62.24 \\
\hline No & 37 & 37.75 \\
\hline Total & $\mathbf{9 8}$ & $\mathbf{1 0 0 \%}$ \\
\hline Table 3. Willingness to Donate Relative's Organs \\
after their Brain Stem Death \\
\hline
\end{tabular}

\begin{tabular}{|c|c|c|}
\hline $\begin{array}{c}\text { Do you Pledge } \\
\text { your Organs here } \\
\text { to Donate after } \\
\text { BSD }\end{array}$ & $\begin{array}{c}\text { Number of } \\
\text { Students }\end{array}$ & Percentage \\
\hline Yes & 68 & 69.38 \\
\hline No & 2 & 2.04 \\
\hline $\begin{array}{l}\text { After Consulting } \\
\text { Family }\end{array}$ & 28 & 28.57 \\
\hline Total & 98 & $100 \%$ \\
\hline \multicolumn{3}{|c|}{$\begin{array}{l}\text { Table 4. Willingness of Participants to Pledge to } \\
\text { Donate the Organs after Brain Stem Death }\end{array}$} \\
\hline
\end{tabular}

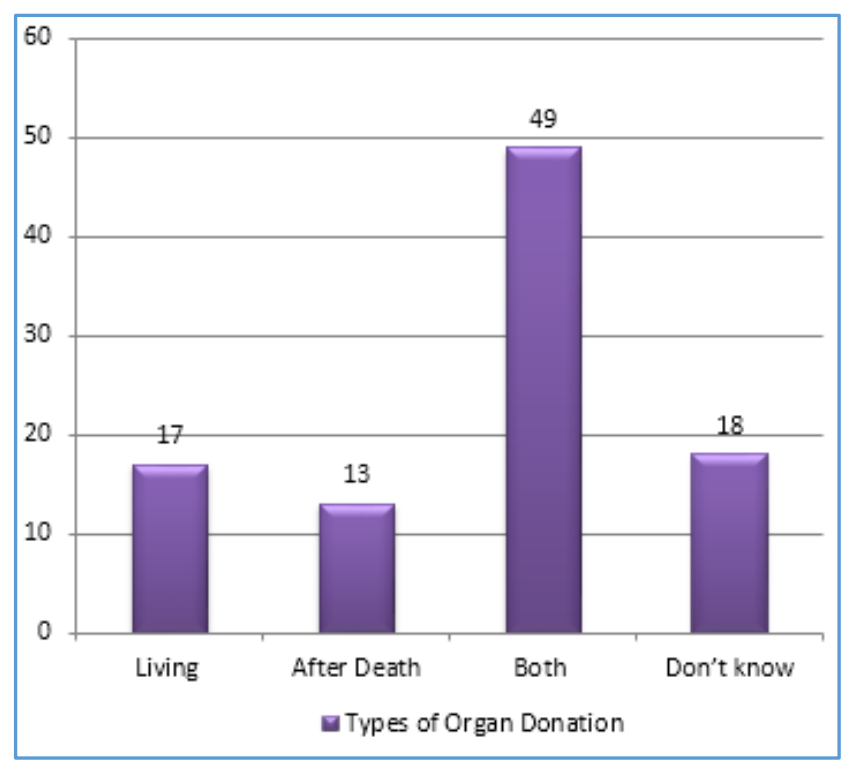

Figure 1. Responses showing Types of Organ Donation 


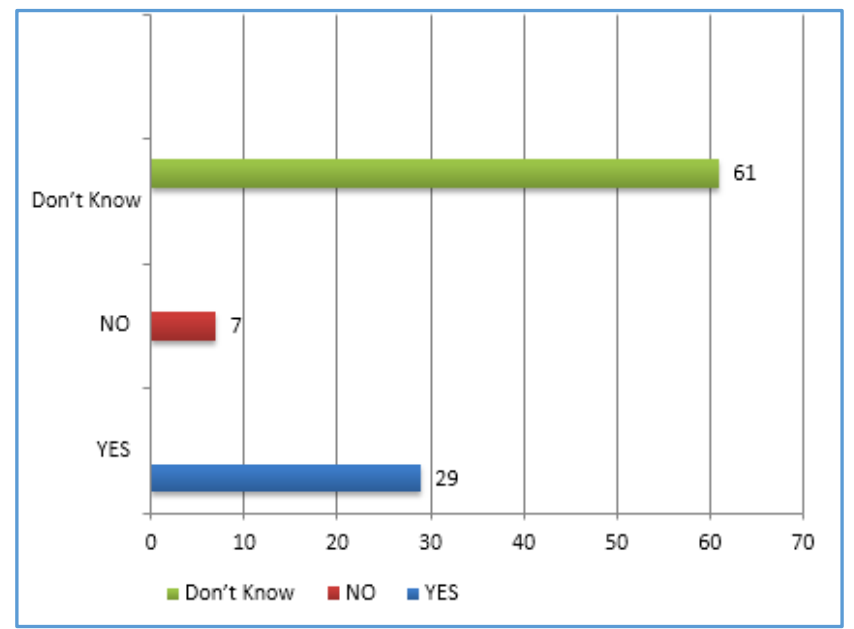

Figure 2. Knowledge about Legal Provisions of Organ Donation

\section{DISCUSSION}

This study was done to assess the knowledge and concerns about Organ Donation in the minds of nursing students in a Tertiary Medical College in Metropolitan area, as very few had accurate knowledge about Organ Donation. Only 50\% participants said that Organ can be donated by Living Donor as well as after death (Figure 1). It shows that though most of the participants have heard about organ donation, they did not have accurate information and it could be a source of spreading wrong information among relatives of patients. As very few participants were found aware about difference between brain stem death and coma. This finding makes it clear that the basic knowledge about brain stem death and organ donation among participants was lacking. Awareness about importance of close relative's consent and without it or in case of family disputes regarding decision on organ donation, organs cannot be donated, was also found lacking among participants which might be one of the important reason behind less commitment towards organ donation. Only few participants were aware about the fact that organ donation in India is supported and regulated by Legislation with several amendments. So from the present study, it is evident that the knowledge regarding organ donation was inadequate among the nursing students and staff as compared to willingness to donate their organs. Ignorance about legal aspects of organ donation, religious acceptance, status of organ donation, fear of procedures, fear about defamation, fear about commercial dealings of organs can be some of the reasons behind lower willingness to donate organs among nurses and therefore this knowledge fails to percolate among population.

\section{CONCLUSION}

Nursing staff is the most important caretaker of the patients when patients are indoor or in intensive care units. Though majority of participants were aware of terminology of Organ Donation, they did not have appropriate knowledge regarding the concept. The knowledge about various types of organ donation and who can donate organs was found to be poor. The most important type of organ donation, i.e. after brain stem death participants were having very less knowledge about definition of brain stem death and difference between BSD and coma. One of the most important step in the process of organ donation is consent of close relatives as a caretaker nursing staff must be aware of this fact in order to facilitate the process and to provide accurate information to the patient's relatives. The information about legislation that control and regulate organ donation is important and nursing staff should be made aware of this fact in order to provide reliable information to the patient's relatives. There is still confusion among minds of participants regarding religious acceptance of organ donation, as almost half of the participants said that they do not know about it. The number of participants willing to donate their organs after their brain stem death was quite satisfactory, i.e. 69\%; it could have been more if participants have accurate information.

\section{Recommendations}

1. Regular organ donation awareness activities should be held at nursing colleges level in order to sensitise nursing students regarding importance of organ donation.

2. Information about brain stem death and basic knowledge regarding organ donation should be included in their nursing academic curriculum.

3. Regular sensitisation workshops should be arranged periodically in order to revise the updated knowledge regarding organ donation and legislation to the nursing staff.

4. Further studies should be conducted in order to find more barriers in the process of Organ donation.

\section{ACKNOWLEDGEMENT}

Special thanks to Regional Zonal Transplant Coordination Committee for providing educational materials and Department of Community Medicine, KEM Hospital for guidance.

\section{REFERENCES}

[1] Babaie M, Hosseini M, Hamissi J, et al. Knowledge, attitude and practice of nurses regarding organ donation. Glob J Health Sci 2015;7(6):129-37.

[2] Shroff S. Legal and ethical aspects of organ donation and transplantation. Indian J Urol 2009;25(3):348-55.

[3] Tam WW, Suen LK, Chan HY. Knowledge, attitudes and commitment toward organ donation among nursing students in Hong Kong. Transplant Proc 2012;44(5):1196-200.

[4] Vinay KV, Beena N, Sachin KS, et al. Changes in knowledge and attitude among medical students towards organ donation and transplantation. Int J Anat Res 2016;4(3):2873-7.

[5] Chakradhar K, Doshi D, Srikanth Reddy B, et al. Knowledge, attitude and practice regarding organ donation among indian dental students. Int J Organ Transplant Med 2016;7(1):28-35.

[6] Dardavessis T, Xenohontos P, Haidich AB, et al. Knowledge, attitude and proposals of medical student concerning transplantations in Greece. Int J Prev Med 2011;2(3):164-9. 